\title{
Penerapan Model Pembelajaran Kooperatif Tipe Think-Pair-Share (TPS) untuk Meningkatkan Motivasi Belajar Tema Hidup Rukun pada Siswa Kelas II
}

\author{
Ni Ketut Suti* \\ SD Negeri 1 Darmasaba, Badung, Indonesia
}

\begin{tabular}{l} 
A R T I C L E I N F O \\
\hline Article history: \\
Received 19 May 2018 \\
Received in revised form \\
25 June 2018 \\
Accepted 10 July 2018 \\
Available online 25 August \\
2018 \\
\hline
\end{tabular}

Kata Kunci:

Think-Pair-Share, motivasi

belajar tematik

Keywords:

Think-Pair-Share, learning motivation

\begin{abstract}
A B S T R A K
Penelitian ini bertujuan untuk meningkatkan motivasi belajar tema hidup rukun pada siswa kelas II SD N 1 Darmasaba semester 1 tahun pelajaran 2016/2017 setelah penerapan model pembelajaran kooperatif tipe Think-Pair-Share (TPS). Jenis penelitian ini adalah penelitian tindakan kelas (PTK) dengan subjek penelitian adalah siswa kelas II SD N 1 Darmasaba yang berjumlah 24 orang. Sedangkan objek dari penelitian ini adalah motivasi belajar siswa dengan penerapan model pembelajaran kooperatif tipe Think-Pair-Share (TPS). Data hasil pelaksanaan pembelajaran dikumpulkan dengan metode observasi. Data yang diperoleh dianalisis menggunakan analisis statistik deskriptif. Berdasarkan hasil analisis data, dapat disimpulkan bahwa penerapan model pembelajaran kooperatif tipe Think-Pair-Share (TPS) dapat meningkatkan motivasi belajar tema Hidup Rukun siswa kelas II SD N 1 Darmasaba semester 1 tahun pelajaran 2016/2017. Hasil ini terbukti dari peningkatan rata-rata motivasi belajar siklus I sebesar 18 menjadi 23 pada siklus II. Ketuntasan klasikal siswa pun mengalami peningkatan dari $75 \%$ pada siklus I menjadi $92 \%$ pada siklus II.
\end{abstract}

\section{A B S T R A C T}

This study aimed at improving the students' motivation to learn by implementing Think-PairShare (TPS) type of cooperative learning model.. The subjects were 24 second grade students of SD N 1 Darmasaba in the first semester of the academic year 2016/2017. The type of this research was classroom action research (CAR). The data collected by observation method. The data obtained were analyzed using descriptive statistical analysis. Based on the results of data analysis, it can be concluded that the application of Think-Pair-Share (TPS) type of cooperative learning model can improve the learning motivation of second grade students of SD N 1 Darmasaba. It can be seen from the improvement of the average of students' learning motivation from cycle I which was 18 to 23 in cycle II. The classical completeness of students also increased from $75 \%$ in the first cycle to $92 \%$ in the second cycle. 


\section{Pendahuluan}

Pendidikan merupakan salah satu kebutuhan yang sangat penting dalam kehidupan masyarakat. Masyarakat dituntut untuk dapat mengikuti perkembangan jaman, untuk dapat mengikuti laju perkembangan jaman tersebut masyarakat memerlukan berbagai cara yang dapat ditempuh, salah satunya adalah pendidikan. Pendidikan menurut Ki Hajar Dewantara (dalam Hasbullah,2009:4) yaitu tuntunan di dalam hidup tumbuhnya anak- anak, adapun maksudnya, pendidikan yaitu menuntun segala kekuatan kodrat yang ada pada anak - anak itu, agar mereka sebagai manusia dan sebagai anggota masyarakat dapatlah mencapai keselamata dan kebahagiaan yang setinggi - tingginya.

Pendidikan memiliki peranan yang sangat penting dalam kehidupan berbangsa dan bernegara, yaitu untuk menjamin kelangsungan kehidupan dan perkembangan bangsa itu sendiri. Hal ini sebagaimana tercantum dalam Undang-Undang Nomor 20 tahun 2003 Tentang Tujuan Pendidikan Nasional, pasal 3 yang berbunyi,

pendidikan untuk mengembangkan kemampuan dan membentuk watak serta peradaban bangsa dalam rangka mencerdaskan kehidupan bangsa, mengembangkan potensi peserta didik agar menjadi manusia yang beriman dan bertaqwa kepada Tuhan Yang Maha Esa, berakhlak mulia, sehat, berilmu, cakap, kreatif, mandiri, dan menjadi warga Negara yang demokratis serta bertanggung jawab.

Untuk mencapai tujuan tersebut maka diselenggarakan beberapa kegiatan pembelajaran yang bersifat formal, non-formal maupun informal dengan berbagai jenjang mulai dari pendidikan usia dini hingga pendidikan tinggi. Rendahnya mutu pendidikan pada setiap jenjang dan satuan pendidikan khususnya pendidikan dasar menjadi persoalan berat yang dihadapi pemerintah. Telah banyak upaya yang dilakukan oleh pemerintah untuk meningkakan kualitas pendidikan. Beberapa upaya yang telah dilakukan pemerintah, yaitu (1) penataran guru terkait sistem pembelajaran, (2) penyediaan sarana dan prasarana penunjang proses pembelajaran, (3) pengadaan bahan ajar dan buku referensi, dan (4) pelaksanaan kegiatan Musyawarah Guru Mata Pelajaran, (5) penyempurnaan kurikulum.

Kurikulum 2013 yang mulai diberlakukan di sekolah dasar bertujuan untuk menghasilkan lulusan yang kompeten, cerdas dan berkarakter mulia sehingga dapat melanjutkan pendidikan ke jenjang yang lebih tinggi. Hal ini hanya dapat tercapai apabila proses pembelajaran yang berlangsung mampu mengembangkan seluruh potensi yang dimiliki siswa. Salah satu dari indikator keberhasilan belajar adalah adanya motivasi belajar, menurut Thomas.L. Good dan Jere B.brophy dalam (Prayitno, Elida.1989: 8) mendefinisikan motivasi belajar sebagai suatu energi penggerak, pengarah dan memperkuat tingkah laku. Suasana pembelajaran yang menyenangkan akan menumbuhkan motivasi pada setiap siswa dalam proses pembelajaran sehingga dapat tercipta suatu interaksi yang harmonis antara siswa dengan guru. Jika itu semua bisa terhubung dengan baik, maka guru akan mendapat kemudahan dalam proses pembelajaran.

Kenyataannya masih banyak ditemui proses pembelajaran yang kurang berkualitas, tidak efisien dan kurang mempunyai daya tarik. Di dalam proses pembelajaran di kelas, guru hanya memberikan cerita di dalam kelas tanpa memfasilitasi siswa untuk bertanya, berpikir dan berdiskusi mengenai permasalahan yang dihadapi oleh siswa pada saat melaksanakan proses pembelajaran. Pembelajaran yang dilakukan oleh guru cenderung hanya memberikan materi kepada siswa dilanjutkan dengan soal-soal tanpa diberikan kesempatan kepada siswa untuk membagikan pengetahuan atau pemecahan masalah yang diperoleh siswa kepada teman sebangku atau teman kelompoknya, sehingga motivasi siswa untuk mengikuti proses pembelajaran menjadi kurang. Padahal didalam proses pembelajaran motivasi siswa sangatlah penting untuk mendorong dan menentukan arah perbuatannya, yakni ke arah tujuan pembelajaran yang hendak dicapai.

Hasil observasi menunjukkan terdapat beberapa kelemahan-kelemahan dalam proses pembelajaran yang dilakukan, (1) siswa terlihat mengalami kebosanan yang ditunjukkan dengan terdapat beberapa siswa yang pandangannya tidak fokus, mengobrol, dan bermain dengan teman sebangku, (2) siswa tidak berperan aktif dalam mengontruksi pengetahuannya saat proses pembelajaran berlangsung, (3) siswa jarang mendapat kesempatan berdiskusi untuk berbagi pengetahuan dengan temannya, (4) siswa jarang mendapat kesempatan untuk mengimplementasikan penemuan konsep yang diperoleh sehingga pengetahuan yang didapatkan siswa menjadi kurang bermakna. Hal ini dapat dilihat dari rendahnya motivasi belajar siswa pada pembelajaran tematik dikelas II SD N 1 Darmasaba. Masih cukup banyak guru yang memakai metode konvensional dalam melaksanakan pembelajaran. Tentu metode konvensional tersebut bukan satu kesalahan, tetapi kalau terus-menerus dipakai maka dapat dipastikan suasana pembelajaran berjalan secara monoton tanpa ada variasi. Salah satu cara yang dapat digunakan untuk meningkatan motivasi belajar siswa adalah dengan menggunakan strategi inovatif dalam pembelajaran salah satunya dengan menggunakan model pembelajaran Think pair share. 
Model pembelajaran Think Pair Share (TPS) merupakan jenis pembelajaran kooperatif yang dirancang dalam bentuk diskusi yang dapat meningkatkan kemampuan berpikir, keterampilan berkomunikasi siswa dan mendorong partisipasi mereka dalam kelas (Azlina, 2010: 23-24). Prosedur yang digunakan dalam model think pair share dapat memberi siswa lebih banyak waktu berpikir, merespon dan saling membantu (Trianto, 2010). Menurut Joyce dkk (2009) latihan bekerja sama bisa dilakukan dengan pengelompokkan sederhana, yakni dengan dua siswa dalam satu kelompok yang ditugaskan untuk menyelesaikan tugas kognitif.

Berbagai hasil penelitian telah membuktikan keberhasilan model pembelajaran Think Pair Share (TPS) dalam meningkatkan motivasi belajar siswa. Hasil penelitian yang dilakukan oleh Surayya (2014) menyatakan bahwa dalam pembelajaran IPA, terdapat pengaruh strategi pembelajaran think pair share terhadap hasil belajar siswa, dan terdapat pengaruh interaksi strategi pembelajaran think pair share dan kemampuan akademik terhadap hasil belajar kognitif siswa ditinjau dari kemampuan berpikir kritis siswa. Selain itu penelitian yang serupa juga pernah dilakukan oleh Azizah (2013) menyatakan bahwa aktivitas belajar siswa meningkat secara signifikan setelah diterapkan model pembelajaran kooperatif tipe think pair share. Penerapan pembelajaran matematika dengan pendekatan struktural metode TPS lebih menekankan partisipasi siswa sehingga pembelajaran lebih menarik. Siswa diberikan kesempatan untuk memikirkan dan memecahkan permasalahan tentang lingkaran dengan pasangannya.

Berdasarkan hal tersebut, penulis terdorong untuk mengangkat permasalahan ini dalam bentuk penelitian dengan judul "penerapan model pembelajaran kooperatif tipe think-pair-share (TPS) untuk meningkatkan motivasi belajar tema hidup rukun pada siswa kelas II SD N 1 Darmasaba semester 1 tahun pelajaran 2016/2017".

\section{Metode}

Penelitian dilaksanakan pada siswa kelas II semester 1 tahun pelajaran 2016/2017 di SD N 1 Darmasaba. Penelitian dilakukan selama empat bulan dari bulan Agustus sampai dengan bulan November 2016. Dalam penelitian ini yang menjadi subjek penelitian adalah siswa SD N 1 Darmasaba kelas II semester 1 tahun pelajaran 2016/2017 sebanyak 24 orang. Objek dalam penelitian tindakan kelas ini yaitu motivasi belajar siswa kelas II SD N 1 Darmasaba semester 1 terhadap penerapan model pembelajaran kooperatif tipe Think-Pair-Share (TPS). Variabel adalah segala sesuatu (sifat-sifat, ciri-ciri, karakteristik) yang menjadi fokus perhatian dalam suatu penelitian (Agung, 2010b). Penelitian ini menggunakan dua jenis variabel yaitu variabel bebas dan variabel tergantung. Menurut Agung (2011), variabel bebas yaitu satu atau lebih dari variabel-variabel yang sengaja dipelajari pengaruhnya terhadap variabel tergantung. Variabel bebas dalam penelitian ini adalah model pembelajaran kooperatif tipe Think-Pair-Share (TPS). Sedangkan variabel tergantung yaitu variabel yang keberadaannya atau munculnya bergantung pada variabel bebas.Variabel tergantungnya yang menjadi fokus perhatian dalam penelitian ini adalah peningkatkan motivasi belajar tematik. Pada penelitian ini yang menjadi tujuan yaitu peningkatkan motivasi belajar siswa setelah menerapan model pembelajaran kooperatif tipe Think-PairShare (TPS).

Dalam penelitian tindakan kelas (PTK) ini mengacu pada teori yang dikemukakan Kemmis dan McNeiff (dalam Santyasa, 2007) Dalam model PTK ini ada empat tahapan pada satu siklus penelitian. Keempat tahapan tersebut terdiri dari: planing, action, observation/evaluation, dan reflection. Pelaksanaan penelitian ini dilakukan dalam dua siklus, dan kedua siklus tersebut dapat digambarkan dalam model seperti gambar sebagai berikut.

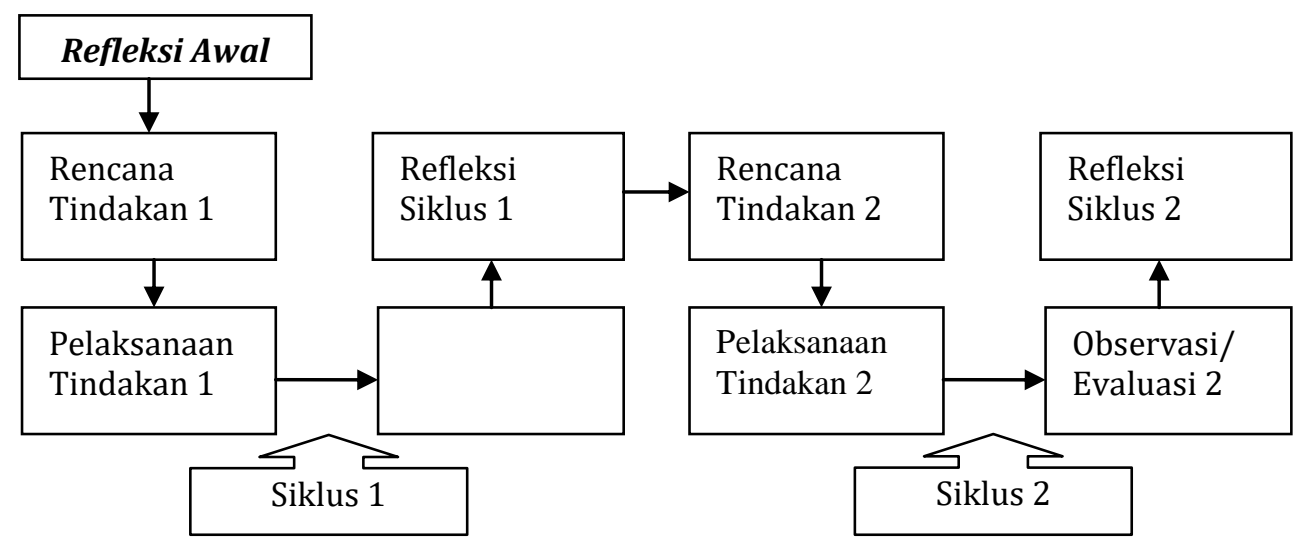

Gambar 01. Model Penelitian Tindakan Kelas Dua Siklus (Agung, 2010) 
Prosedur penelitian disesuaikan dengan rancangan penelitian yaitu penelitian tindakan kelas (PTK). Menurut Suharsimi, dkk. (2007:3)"penelitian tindakan kelas merupakan suatu pencermatan terhadap kegiatan belajar berupa sebuah tindakan, yang sengaja dimunculkan dan terjadi di sebuah kelas bersama". Pada bagian lain, Hopkins dan Kemmis (dalam Wiriaatmaja 2008:11) mengemukakan bahwa PTK adalah: a) Hopkins (1993) menyatakan penelitian tindakan kelas adalah penelitian yang mengkombinasi prosedur penelitian dengan tindakan substantif, suatu tindakan yang dilakukan dalam disiplin inkuiri, atau suatu usaha seseorang untuk memahami apa yang sedang terjadi, sambil terlibat dalam sebuah proses perbaikan dan perubahan. Sedangkan, Kemmis (1983) menjelaskan bahwa penelitian tindakan kelas adalah sebuah bentuk inkuiri reflektif yang dilakukan secara kemitraan mengenai situasi sosial tertentu (termasuk pendidikan) untuk meningkatkan rasionalitas dan keadilan dari a) kegiatan praktek sosial atau pendidikan mereka b) pemahaman mereka mengenai kegiatankegiatan praktek pendidikan, dan c) situasi yang memungkinkan terlaksananya kegiatan praktek.

Berdasarkan definisi di atas, dapat disimpulkan bahwa penelitian tindakan kelas merupakan suatu penelitian tindakan yang dimunculkan di kelas untuk memperbaiki praktik pembelajaran guna meningkatkan mutu pembalajaran.

Dalam penelitian ini, peneliti merancang penelitian yang akan dilaksanakan dan menyiapkan instrumen evaluasi/observasi serta mengobservasi guru pada saat mengelola pembelajaran berdasarkan sintaks/langkah-langkah model pembelajaran yang digunakan. Guru ikut terlibat dalam pembelajaran dan perencanaan tindakan yang akan dilaksanakan, serta melaksanakan pembelajaran sesuai dengan skenario yang sudah disiapkan bersama. Penelitian ini direncanakan dalam dua siklus, tiap siklus terdiri dari empat tahapan yaitu perencanaan, pelaksanaan, observasi, dan refleksi. Jika sudah memenuhi hasil yang diharapkan maka siklus tidak dilanjutkan lagi.

Untuk mengumpulkan data dalam penelitian ini menggunakan metode observasi. Metode observasi merupakan metode yang sering dipakai oleh guru guna memperoleh data motivasi atau aktivitas belajar. Menurut Agung (2011:60) "metode observasi adalah metode pengumpulan data dengan melakukan pengamatan terhadap siswa". Pengamatan tersebut dilakukan secara berulang-ulang di setiap pembelajaran sehingga dapat menyimpulkan peningkatan motivasi belajar siswa.

Setelah data dalam penelitian ini terkumpul selanjutnya dilakukan analisis data. Ada dua jenis metode analisis statistik yaitu metode analisis statistik deskriptif kuantitatif. Dalam hubungannya, Agung (2011:61) menjelaskan bahwa: metode analisis statistik deskriptif ialah suatu cara pengolahan data yang dilakukan dengan jalan menerapkan rumus-rumus statistik deskriptif seperti: distribusi frekuensi, grafik, angka rata-rata (Mean), median (Me), modus (Mo) untuk menggambarkan suatu objek/variabel tertentu, sehingga diperoleh kesimpulan umum.

Dalam penerapan metode analisis statistik deskriptif ini, data yang diperoleh dari hasil penelitian dianalisis dan disajikan ke dalam: a) menghitung angka rata-rata (Mean), b) menghitung median, c) menghitung modus. Mean, median modus dihitung dengan bantuan Microsoft excel.

Indikator keberhasilan pelaksanaan ini, berpedoman pada kriteria berikut. Tingkat keberhasilan dalam penelitian ini adalah apabila rata-rata motivasi belajar Siswa minimal pada kategori Tinggi, dan ketuntasan klasikal sebesar $90 \%$.

\section{Hasil dan Pembahasan}

Kegiatan Penelitian Tindakan Kelas ini dilakukan di SD N 1 Darmasaba. Subjek penelitian ini adalah siswa kelas II tahun pelajaran 2016/2017 yang berjumlah 24 orang. Objek dari penelitian ini adalah penerapan model pembelajaran kooperatif tipe Think-Pair-Share (TPS) untuk meningkatkan motivasi belajar siswa.

Hasil observasi menunjukkan terdapat beberapa kelemahan-kelemahan dalam proses pembelajaran yang dilakukan, (1) siswa terlihat mengalami kebosanan yang ditunjukkan dengan terdapat beberapa siswa yang pandangannya tidak fokus, mengobrol, dan bermain dengan teman sebangku, (2) siswa tidak berperan aktif dalam mengontruksi pengetahuannya saat proses pembelajaran berlangsung, (3) siswa jarang mendapat kesempatan berdiskusi untuk berbagi pengetahuan dengan temannya, (4) siswa jarang mendapat kesempatan untuk mengimplementasikan penemuan konsep yang diperoleh sehingga pengetahuan yang didapatkan siswa menjadi kurang bermakna. Hal ini dapat dilihat dari rendahnya motivasi belajar siswa pada pembelajaran tematik dikelas II SD N 1 Darmasaba. Masih cukup banyak guru yang memakai metode konvensional dalam melaksanakan pembelajaran. Tentu metode konvensional tersebut bukan satu kesalahan, tetapi kalau terus-menerus dipakai maka dapat dipastikan suasana pembelajaran berjalan secara monoton tanpa ada variasi. Salah satu cara yang dapat digunakan untuk meningkatan motivasi belajar siswa adalah dengan menggunakan strategi inovatif dalam pembelajaran salah satunya dengan menggunakan model pembelajaran Think pair share. 
Penelitian yang dilakukan meliputi 4 tahapan yaitu perencanaan, pelaksanaan, observasi dan refleksi. Pada kegiatan perencanaan tindakan, peneliti menyiapkan rancangan penelitian, menyiapkan rencana pembelajaran, menyiapkan kisi - kisi soal (Indikator soal), dan menyiapkan alat evaluasi. Pada kegiatan pelaksanaan proses pembelajaran pada siklus I, kegiatan pembelajaran dilakukan sebanyak tiga kali pertemuan. Kegiatan yang dilakukan pada pelaksanaan proses pembelajaran mengacu pada rencana pelaksanaan pembelajaran yang telah dibuat pada rencana tindakan. Untuk memperoleh data tentang motivasi belajar siswa pada siklus pertama maka diadakan observasi melalui lembar observasi yang telah dibuat.

Berdasarkan pemaparan di atas, pada siklus I Rata-rata motivasi belajar siswa= 18 yang dikonvesikan ke dalam PAP skala lima, berada pada tingkat motivasi $20>\mathrm{X}>16$ yang berarti bahwa tingkat motivasi belajar siswa siklus I tergolong sedang. Ketuntasan klasikalnya $=75 \%$, karena belum semua siswa memiliki motivasi yang tinggi, masih ada 6 orang yang mendapatkan rata-rata motivasi rendah.

Kendala yang dihadapi pada siklus I adalah guru belum mampu menciptakan suasana belajar aktif dan menyenangkan, belum semua siswa memahami materi pembelajaran yang disampaikan, kerjasama antar sesama siswa masih kurang, dan masih banyak siswa yang lain-lain saat guru menjelaskan.

Kendala tersebut diatasi dengan memaksimalkan pelaksanaan model Pembelajaran Kooperatif TPS sehingga pembelajaran lebih menyenangkan, mengajak siswa untuk berkonsentrasi pada pelajarannya, menumbuhkan kerjasama dan gotong royong pada siswa dengan mengajak melakukan pembelajaran yang bermakna.

Berdasarkan pemaparan di atas, kategori motivasi belajar siswa berada pada kategori sedang dan ketuntasan siswa tidak mencapai 90\% sehingga belum mencapai kategori dan kategori yang ditetapkan oleh peneliti, yakni kategori motivasi belajar siswa berada pada kategori minimal tinggi dan dan ketutasan klasikal 90\%. Sehingga dapat disimpulkan bahwa siklus I belum berhasil dan harus diadakan siklus II dengan memperhatikan kendala-kendala yang dihadapi siklus I.

Berdasarkan pemaparan di atas, pada siklus II rata-rata motivasi belajar siswa= 23 yang dikonvesikan ke dalam PAP skala lima, berada pada tingkat motivasi X> 24 yang berarti bahwa tingkat motivasi belajar siswa siklus II tergolong tinggi. Ketuntasan klasikalnya $=92 \%$. Hal ini menunjukkan bahwa kendala-kendala yang dihadapi pada siklus I sudah dapat diatasi pada siklus II. Maka dari itu kriteria ketuntasan minimal baik dan ketuntasan klasikal 90\% sudah terpenuhi sehingga penelitian pada siklus II dinyatakan berhasil dan siklus dihentikan.

Untuk lebih jelasnya, peningkatan motivasi belajar dari siklus I ke siklus II dapat digambarkan dalam grafik. Grafik motivasi belajar siswa pada siklus I dan siklus ke II meliputi : nilai rata - rata kelas, dan ketuntasan klasikal. Terlihat peningkatan yang signifikan antara motivasi belajar siswa pada dari siklus I ke siklus II sehingga dapat disimpulkan bahwa penerapan model pembelajaran kooperatif tipe Think-Pair-Share (TPS) dapat meningkatkan motivasi belajar tema Hidup Rukun siswa kelas II SD N 1 Darmasaba semester 1 tahun pelajaran 2016/2017.

\section{Simpulan dan Saran}

Berdasarkan hasil penelitian yang telah dibahas pada bab IV, maka dapat dapat disimpulkan bahwa penerapan model pembelajaran kooperatif tipe Think-Pair-Share (TPS) dapat meningkatkan motivasi belajar tema Hidup Rukun siswa kelas II SD N 1 Darmasaba semester 1 tahun pelajaran 2016/2017. Hasil ini terbukti dari peningkatan rata-rata motivasi belajar siklus I sebesar 18 menjadi 23 pada siklus II. Ketuntasan klasikal siswa pun mengalami peningkatan dari 75\% pada siklus I menjadi 92\% pada siklus II.

Saran yang dapat disampaikan berdasarkan penelitian yang telah dilakukan adalah sebagai berikut, 1) Siswa diharapkan mampu mengembangkan kemampuannya. Belajar lebih giat lagi agar mampu mendapatkan hasil belajar yang maksimal. 2) Guru diharapkan mampu untuk selalu berinovasi dalam pembelajaran yang di belajarkannya supaya siswa tidak jenuh dan termotivasi untuk mengikuti pembelajaran yang diberikan oleh guru. 3) Kepala sekolah dalam mengambil kebijakan hendaknya selalu mendukung upaya-upaya positif guru maupun siswa untuk meningkatkan kualitas dan kuantitas pembelajaran.

\section{Daftar Rujukan}

Agung, A. A. G. 2011. Metodologi Penelitian Pendidikan. Singaraja: Undiksha Singaraja.

Arikunto, Suharsimi. 2002. Dasar-dasar Evaluasi Pendidikan. Edisi Revisi. Jakarta: Bumi Akara. 
Arta Negara, I Komang. 2007. Pengaruh Strategi Think Pair Share (TPS) Berfasilitas Program Aplikasi Power Point Terhadap Hasil Belajar IPA (Biologi) Siswa SMP Negeri 1 Banjar Kelas VIII Semester Ganjil Tahun Ajaran 2008/2009. Skripsi (tidak diterbitkan). Jurusan Teknologi Pendidikan, Undiksha Singaraja.

Azizah. 2013. "Penerapan Pendekatan Struktural Metode Think Pair Share (Tps) Pada Materi Lingkaran Untuk Meningkatkan Aktivitas Belajar Matematika Siswa ". Tersedia pada e-Journal Program Pascasarjana Universitas Pendidikan Ganesha Program Studi IPA Volume 7 Tahun 2013

Cece. 1987. Upaya Pembaharuan dalam Pendidikan dan Pengajaran. Bandung: PT Remaja Rosdakarya.

Departemen Pendidikan Nasional, 2003. Undang-Undang Nomor 20 Tahun 2003 Tentang Sistem Pendidikan Nasional. Jakarta: Depdiknas.

Endang \& Nuryata. 2010. Pembelajaran Masa Kini. Jakarta: Business Center SMKN 7 Jakarta Timur.

Ibrahim et.al. 2002. Pembelajaran Kooperatif. Cetakan pertama. Surabaya: Unise

Joyce B., Weil M., and Calhoun E. 2009. Models of Teaching : Model-model Pengajaran. Yogyakarta: Pustaka Belajar.

Mertasari, Ni Made Sri. 2003. "Pengaruh Model Tes Terhadap Motivasi Belajar Matematika dengan Mempertimbangkan Tingkat Kesukaran Tes". Tesis (tidak diterbitkan). Singaraja: IKIP Negeri Singaraja.

Sardiman. 2007. Interaksi dan Motivasi. Jakarta: PT. Raja Grafindo Persada.

Slavin, R.E.1997. Educational Psychology Teory and Practice. $5^{\text {th }}$ (ed). Singapore: Allyn and Bacon.

Suparya, I Kt. 2010. Pengaruh model pembelajaran kooperatif tipe think talk write (ttw) terhadap hasil belajar dan kemampuan berpikir kritis pada pembelajaran sains di sekolah dasar, Tesis (tidak diterbitkan) Universitas Pendidikan Ganesha.

Surayya. 2014. "Pengaruh Model Pembelajaran Think Pair Share Terhadap Hasil Belajar Ipa Ditinjau Dari Keterampilan Berpikir Kritis Siswa". Tersedia pada e-Journal Program Pascasarjana Universitas Pendidikan Ganesha Program Studi IPA Volume 4 Tahun 2014.

Suteja, Wayan. 2007. "Kontribusi Kecerdasan, Motivasi Belajar, dan Lingkungan Keluarga Terhadap Prestasi Belajar Siswa Kelas X SMA Negeri 1 Selat Karangasem". Skripsi (tidak diterbitkan). Jurusan Bimbingan Konseling Fakultas Ilmu Pendidikan Undiksha Singaraja.

Trianto. 2007. Model-Model Pembelajaran Inovatif Berbasis Konstruktivistik. Jakarta: Prestasi Pustaka.

2010. Mendesain Model Pembelajaran Inovatif - Progresif. Jakarta : Kencana Prenada Media. University Press. 